\title{
Impact of NICRA Project Interventions on Knowledge and Awareness Level of Farmers on Climate Resilient Agro-Technologies
}

\author{
S. Sultana ${ }^{1 *}$, P. Das ${ }^{2}$, I. Barman ${ }^{2}$ and S. Barman ${ }^{3}$ \\ ${ }^{1}$ APART, Krishi Vigyan Kendra, Barpeta, India \\ ${ }^{2}$ Department of Extension Education BN college of Agriculture, \\ Assam Agricultural University, Biswanath Chariali, India \\ ${ }^{3}$ Department of Extension Education, Assam Agricultural University, Jorhat-13, India \\ *Corresponding author
}

\section{Keywords}

Knowledge, Awareness, climate resilient agrotechnologies, farmers

\section{Article Info}

Accepted:

18 May 2020

Available Online:

10 June 2020

\begin{abstract}
A B S T R A C T
The present study was conducted in Lakhimpur district of Assam to measure the level of knowledge and awareness of farmers on climate resilient agro-technologies. A total of 160 farmers, 80 NICRA (National Innovations on climate resilient agriculture) participant farmers and 80 non-participant farmers were selected randomly from the 8 purposively selected villages. The findings of the study revealed that majority of the participant farmers $(56.25 \%)$ had medium level of knowledge while for nonparticipant farmers $(83.75 \%)$ had low level knowledge on climate resilient agro-technologies. The $t-$ value 3.47 indicates significant difference of knowledge level between two group of famers which may be due to intervention of INCRA project. It was seen that all the participant farmers $(100 \%)$ were aware about all the fourteen climate resilient agro-technologies considered in the study, while differential level of awareness was observed among the nonparticipant farmers. The percentage of non-participant farmers varied from 31.25 per cent to 93.75 percent as regards to their level of awareness regarding the climate resilient agrotechnologies under consideration. The existing extension efforts made under the project need to be strengthened and streamlined to enhance the knowledge and awareness level of participant farmers on climate resilient agro-technologies.
\end{abstract}

\section{Introduction}

Climate change is become the burning issue throughout the world. The adverse effect of climate change is mostly affected to poor people. The impact of climate change on agriculture and food security is now a major concern for UNO and considered as one of the important goal of millennium development goal. There is now evident that the increase of global temperature and changes of rainfall rate is observed during $20^{\text {th }}$ century throughout the world. According to the World Bank Report (2015) without urgent action, climate impacts could push an additional 100 million people into poverty by 2030. Climate change poses a threat to food access for both rural and urban populations by 
reducing agricultural production and incomes, increasing risks and disrupting markets. Poor producers, the landless and marginalized ethnic groups are particularly vulnerable (Olsson, et al., 2014). There is a significant importance of climate resilient innovations in the present day, most commonly in the agricultural sector. So, it is necessary to introduce climate resilient agro-technologies so that the farmers can adapt to the changing climate vulnerability. Realising the situation in Assam different climate resilient agro technologies were introduced under NICRA project in some selected districts vulnerable to climate change.

The technological interventions in terms climate resilient agriculture technology have been provided to farmers by the All India Coordinated Research Project on Dry land Agriculture under NICRA project in Lakhimpur districts. Awareness and proper knowledge about climate resilient agriculture technology are very important for the farmers to cope up with adverse effect of climate change or variability. The present study was conducted in Lakhimpur district of Assam to assess the impact of NICRA project in terms of level of knowledge and awareness of the farmers on climate resilient agrotechnologies.

\section{Materials and Methods}

The present study was undertaken in Lakhimpur district of Assam to measure the level of knowledge and awareness of farmers on climate resilient agro-technologies introduced under the NICRA Project. A total of 160 farmers, 80 NICRA participant farmers and 80 non-participant farmers were selected randomly from the 8 purposively selected villages. A knowledge test was used to assess the knowledge level for the purpose. A total of 26 items was administered to both the group of sample farmers.
The knowledge level of a respondent on climate resilient agro-technology was indicated by the total score received by him on the test. The answers for the questions in the knowledge test were in dichotomous categories. In computing the knowledge scores of the respondents, correct answer to a question was given one score and for incorrect answer was given zero score. The total score on the test had a theoretical range of 0 to 26. The intrinsic validity of the test was estimated by taking the square root of the reliability coefficient (Guilford, 1954). The reliability of the test was estimated with the help of split-half method (odd-even design) by applying the following formula (Rulon,1939).

$$
r_{t t}=1-\frac{S_{d}^{2}}{S_{t}^{2}}
$$

Where, $r_{t t}$ stands for reliability coefficient of the total test scores, $\mathrm{d}$ is the difference between two half scores, $S_{d}$ is the standard deviation of those differences and $S_{t}$ is the standard deviation of total test scores. Based on the mean $(\bar{X})$ and standard deviations (S.D.) of the obtained scores, respondents were classified into three categories as shown below:

\begin{tabular}{|l|l|}
\hline Categories & Score range \\
\hline Low & Below 22 \\
\hline Medium & $22-24$ \\
\hline High & Above 24 \\
\hline
\end{tabular}

To measure the level of awareness fourteen climate resilient agro-tehnologies were considered and the farmers were categorised as Aware/unaware against each climate resilient agro-technology. After that the frequency and percentage of each category was calculated. Frequency, mean, SD, CV and $\mathrm{t}$ - test were the statistical tools used for analysis and interpretation of data. 


\section{Results and Discussion}

Knowledge on climate resilient agrotechnologies of participant and nonparticipant farmers

It is evident from Table 1 that majority of the participant farmers $(56.25 \%)$ had medium level of knowledge on climate resilient agrotechnologies, followed by 20.00 per cent respondents with high level of knowledge. Only 15.00 per cent of the participant farmers were found with low level of knowledge .The co-efficient of variation $(8.01 \%)$ indicated that the participant farmer respondents were highly homogeneous with respect to their level of knowledge on climate resilient agrotechnologies. Regarding the level of knowledge on climate resilient agrotechnologies of the non-participant farmers, majority of them $(83.75 \%)$ had low level of knowledge, followed by 16.25 per cent with medium level of knowledge. None of the nonparticipant farmers were found with high level of knowledge on climate resilient agrotechnologies. The co-efficient of variation $(40.93 \%)$ indicated that the non-participant farmer respondents were relatively heterogeneous with respect to their level of knowledge on climate resilient agrotechnologies. The mean knowledge level score of participant farmers (23.08) was much higher than that of the non-participant farmers (12.85).The difference between the mean level of knowledge on climate resilient agrotechnologies of participant and nonparticipant farmers were 10.23. The significance of the difference between two sample means was tested by employing t-test. The ' $t$ ' value was found to be significant at 0.01 level and it indicates that the project interventions had significant impact on the participant farmer's level of knowledge on climate resilient agro-technologies introduced under the project.

Awareness of participant and nonparticipant farmers about climate resilient agro-technologies

The findings presented in Table 2 revealed that all the participant farmers $(100 \%)$ were aware about all the fourteen climate resilient agro-technologies considered in the study, while differential level of awareness was observed among the non-participant farmers regarding the climate resilient agrotechnologies considered in the study.

Table.1 Distribution of respondents according to their level of knowledge on climate resilient agro-technology $n=160$

\begin{tabular}{|c|c|c|c|c|c|c|c|}
\hline \multirow{2}{*}{$\begin{array}{l}\text { Category of } \\
\text { farmers }\end{array}$} & \multicolumn{3}{|c|}{ Level of knowledge } & \multirow[t]{2}{*}{ Mean } & \multirow[t]{2}{*}{ SD } & \multirow[t]{2}{*}{$\mathbf{C V}$} & \multirow[t]{2}{*}{ t value } \\
\hline & Low & Medium & High & & & & \\
\hline Participant & $15(18.75)$ & $45(56.25)$ & $20(25.00)$ & 23.08 & 1.85 & 8.01 & $3.47 *$ \\
\hline Non participant & $67(83.75)$ & $13(16.25)$ & $0(0.00)$ & 12.85 & 5.26 & 40.93 & \\
\hline
\end{tabular}


Table.2 Distribution of respondents according to level of awareness on climate resilient agro-technology $n=160$

\begin{tabular}{|c|c|c|c|c|}
\hline \multirow[t]{2}{*}{ Climate resilient agro-technology } & \multicolumn{2}{|c|}{$\begin{array}{l}\text { Number of Participant } \\
\text { farmers }\end{array}$} & \multicolumn{2}{|c|}{$\begin{array}{l}\text { Number of Non- } \\
\text { participant farmers }\end{array}$} \\
\hline & Aware & Not aware & Aware & Not aware \\
\hline $\begin{array}{l}\text { 1. Growing short duration sali rice } \\
\text { cultivar for dry spell management }\end{array}$ & $\begin{array}{c}80 \\
(100.00)\end{array}$ & $\begin{array}{c}0 \\
(0.00)\end{array}$ & $\begin{array}{c}80 \\
(100.00)\end{array}$ & $\begin{array}{c}0 \\
(0.00)\end{array}$ \\
\hline $\begin{array}{l}\text { 2. Growing medium duration sali } \\
\text { rice cultivar for dry spell } \\
\text { management }\end{array}$ & $\begin{array}{c}80 \\
(100.00)\end{array}$ & $\begin{array}{c}0 \\
(0.00)\end{array}$ & $\begin{array}{c}80 \\
(100.00)\end{array}$ & $\begin{array}{c}0 \\
(0.00)\end{array}$ \\
\hline $\begin{array}{l}\text { 3. Growing alternate crops for dry } \\
\text { spell management }\end{array}$ & $\begin{array}{c}80 \\
(100.00)\end{array}$ & $\begin{array}{c}0 \\
(0.00)\end{array}$ & $\begin{array}{c}55 \\
(68.75)\end{array}$ & $\begin{array}{c}25 \\
(31.25)\end{array}$ \\
\hline $\begin{array}{l}\text { 4. Crop diversification for dry spell } \\
\text { management }\end{array}$ & $\begin{array}{c}80 \\
(100.00)\end{array}$ & $\begin{array}{c}0 \\
(0.00)\end{array}$ & $\begin{array}{c}65 \\
(81.75)\end{array}$ & $\begin{array}{c}15 \\
(18.75)\end{array}$ \\
\hline $\begin{array}{l}\text { 5. Growing hybrid maize cultivar in } \\
\text { the driest period of the year }\end{array}$ & $\begin{array}{c}80 \\
(100.00)\end{array}$ & $\begin{array}{c}0 \\
(0.00)\end{array}$ & $\begin{array}{c}80 \\
(100.00)\end{array}$ & $\begin{array}{c}0 \\
(0.00)\end{array}$ \\
\hline $\begin{array}{l}\text { 6. Rain water harvesting in farm } \\
\text { ponds and use of harvested rain for } \\
\text { irrigation of rabi crops }\end{array}$ & $\begin{array}{c}80 \\
(100.00)\end{array}$ & $\begin{array}{c}0 \\
(0.00)\end{array}$ & $\begin{array}{c}80 \\
(100.00)\end{array}$ & $\begin{array}{c}0 \\
(0.00)\end{array}$ \\
\hline $\begin{array}{l}\text { 7. Rain water harvesting in farm } \\
\text { ponds and use of harvested rain } \\
\text { water for raising seedling of sali rice }\end{array}$ & $\begin{array}{c}80 \\
(100.00)\end{array}$ & $\begin{array}{c}0 \\
(0.00)\end{array}$ & $\begin{array}{c}80 \\
(100.00)\end{array}$ & $\begin{array}{c}0 \\
(0.00)\end{array}$ \\
\hline $\begin{array}{l}\text { 8. Use of organic manure (vermi- } \\
\text { compost/compost) }\end{array}$ & $\begin{array}{c}80 \\
(100.00)\end{array}$ & $\begin{array}{c}0 \\
(0.00)\end{array}$ & $\begin{array}{c}80 \\
(100.00)\end{array}$ & $\begin{array}{c}0 \\
(0.00)\end{array}$ \\
\hline 9. Diversification of Farming system & $\begin{array}{c}80 \\
(100.00)\end{array}$ & $\begin{array}{c}0 \\
(0.00)\end{array}$ & $\begin{array}{c}55 \\
(68.75)\end{array}$ & $\begin{array}{c}25 \\
(31.25)\end{array}$ \\
\hline $\begin{array}{l}\text { 10. Application of NPK for drought } \\
\text { management in sali rice }\end{array}$ & $\begin{array}{c}80 \\
(100.00)\end{array}$ & $\begin{array}{c}0 \\
(0.00)\end{array}$ & $\begin{array}{c}25 \\
(31.25)\end{array}$ & $\begin{array}{c}55 \\
(68.75)\end{array}$ \\
\hline $\begin{array}{l}\text { 11. Animal feed management } \\
\text { through growing of fodder crops }\end{array}$ & $\begin{array}{c}80 \\
(100.00)\end{array}$ & $\begin{array}{c}0 \\
(0.00)\end{array}$ & $\begin{array}{c}75 \\
(93.75)\end{array}$ & $\begin{array}{c}5 \\
(6.25)\end{array}$ \\
\hline $\begin{array}{l}\text { 12. Protected cultivation of high } \\
\text { value crops }\end{array}$ & $\begin{array}{c}80 \\
(100.00)\end{array}$ & $\begin{array}{c}0 \\
(0.00)\end{array}$ & $\begin{array}{c}60 \\
(75.00)\end{array}$ & $\begin{array}{c}20 \\
(25.00)\end{array}$ \\
\hline 13. Double cropping & $\begin{array}{c}80 \\
(100)\end{array}$ & $\begin{array}{c}0 \\
(0.00)\end{array}$ & $\begin{array}{c}65 \\
(81.25)\end{array}$ & $\begin{array}{c}15 \\
(18.75)\end{array}$ \\
\hline $\begin{array}{l}\text { 14. In-situ rain water harvesting for } \\
\text { moisture conservation (mulching) }\end{array}$ & $\begin{array}{c}80 \\
(100.00)\end{array}$ & $\begin{array}{c}0 \\
(0.00)\end{array}$ & $\begin{array}{c}80 \\
(100.00)\end{array}$ & $\begin{array}{c}0 \\
(0.00)\end{array}$ \\
\hline
\end{tabular}

Figures within parentheses indicate percentage 
All of the non-participant farmers (100.00\%) were found to be aware of the climate resilient agro-technologies, viz., growing short duration sali rice cultivar for dry spell management, growing medium duration sali rice cultivar for dry spell management, growing hybrid maize cultivar in the driest period of the year, rain water harvesting in farm ponds and use of harvested rain for irrigation of rabi crops, use of organic manure (vermi-compost/compost) and in-situ rain water harvesting for moisture conservation (mulching). The percentage of non-participant farmers varied from 31.25 per cent to 93.75 percent as regards to their level of awareness regarding the other climate resilient agrotechnologies under consideration.

Findings on knowledge level of participant farmers on climate resilient agro-technologies revealed that majority of the participant farmers had medium level of knowledge. This implies that existing extension educational efforts made under the project need to be strengthened and streamlined to enhance the knowledge and awareness level of participant farmers on climate resilient agrotechnologies.

\section{References}

Anonymous (2015). NICRA Annual Report: 2014-15; AICRP on Dryland Agriculture, Biswanath Chariali Centre, Biswanath College of Agriculture, AAU, Biswanath Chariali.

Bloom,B.S.(1956). Taxonomy of Educational Objectives; The Classification of Educational Goals. Handbook 1, Cognitive Domain. New York. McKay Co.Inc.

Guilford, J.P. and B. Fruchter (1978). Fundamental Statistics in Psychology and education (6th ed). Tokyo, Mc Graw Hill- Kogakusha Ltd.

Rulon, P.J. (1939). A Simplified Procedure for Determining the Reliability of a Test by Split Halves. Harr. Educ.Rev.9. 99103

Olsson, L., M. Opondo, P. Tschakert, A. Agrawal, S.H. Eriksen, S. Ma, L.N. Perch, and S.A. Zakieldeen(2014). Livelihoods and poverty. Cambridge University Press, Cambridge, United Kingdom and New York, NY, USA,:793-832.

\section{How to cite this article:}

Sultana. S., P. Das, I. Barman and Barman. S. 2020. Impact of NICRA Project Interventions on Knowledge and Awareness Level of Farmers on Climate Resilient Agro-Technologies. Int.J.Curr.Microbiol.App.Sci. 9(06): 1002-1006. doi: https://doi.org/10.20546/ijcmas.2020.906.125 